\title{
United Kingdom Effort to Combat COVID-19: Learn-to-reflect Policy
}

\section{Upaya Inggris Menghadapi COVID-19: Kebijakan Learn-To-Reflect}

\author{
Gusti Ayu Meisa Kurnia Dewi Silakarma \\ MA Development Studies Graduate, Institute of Development \\ Studies, University of Sussex
}

\begin{abstract}
Abstrak
Hingga saat ini, belum ada basis indikator internasional yang diterapkan sebelum COVID-19-baik indikator kesehatan, ekonomi, maupun sosial-politik-yang dapat digunakan untuk memprediksi bagaimana performa tiap negara dalam merespons COVID-19. Negara dengan ekonomi yang besar belum tentu dapat merespons pandemi dengan mumpuni. Dinamika yang tidak jauh berbeda juga dialami oleh Inggris. Inggris masih menempati posisi ketiga tertinggi di wilayah Eropa dengan kasus kumulatif COVID-19 per Agustus 2020. Pun ini diperumit dengan tingkat kematian di Inggris sebagai persentase tertinggi di Eropa. Hal ini membuat kebijakan Inggris terkait COVID-19 menarik untuk dikaji. Analisis kebijakan ini didasari pada lensa syndemic yang menekankan pentingnya implikasi non-kesehatan untuk diinkorporasi dalam pembuatan kebijakan serta whole-of-society menggarisbawahi koordinasi aktor-aktor negara dan non-negara penting untuk proses implementasi. Temuan tulisan ini ialah kebijakan pemerintah Inggris berbentuk learn-to-reflect; mencoba inklusif dan holistik serta berhasil menekan pertumbuhan kasus baru, namun observasi mendatang antara koordinasi aktor dalam multisektor isu terhadap efektivitas kebijakan jangka panjang masih diperlukan.
\end{abstract}

Kata-Kata Kunci: Inggris; COVID-19; Syndemic-Pandemic; Whole-Of-Society; Kolaborasi Pemerintahan; Ketimpangan

To date, no fixed international indicators set prior to the start of COVID-19-either health, economics, or socio-politics indicators-can be used to predict how states' policies fared in responding to COVID-19. A state with an enormous economic power does not necessarily equip to respond the pandemic adequately. The United Kingdom (UK) has encountered similar dynamic. The UK remains as the third country with the most cumulative cases of COVID-19 in the Europe as per August 2020. This was complicated by the UK's COVID-19 CFR that remains the highest in the Europe. This brought to light a puzzle in how the UK implement its COVID-19 policy. The analysis in this study utilized a syndemic lens in which emphasises the importance of non-health issues to be incorporated into the policy, as well as, the whole-of-society approach where state and non-state actors' coordination remains significant. The findings on UK policy response mimicked a model of learn-to-reflect; trying to be inclusive and holistic, as well as successfully reduced new daily COVID-19 cases, yet, the upcoming observation on the coordination between actors on multisectoral issues and how this affects the effectiveness of long-term policy remains as an utmost necessity.

Keywords: United Kingdom; COVID-19; Syndemic-Pandemic; Whole-Of-Society; Governance Collaboration; Inequality 
COVID-19, pandemi yang terdeteksi pada tahun 2019 masih berlangsung hingga sekarang. Penyakit ini disebabkan oleh virus severe acute respiratory syndrome coronavirus (SARSCoV-2) pertama kali ditularkan dari hewan ke manusia di Wuhan, Tiongkok (ECDC 2020b; ECDC 2020c). Meskipun tingkat kematian (case fatality rate/CFR) COVID-19 (3,4\%) tidak setinggi Ebola yang mematikan setengah penderitanya (50\%) atau SARSCoV-1 yang menelan jiwa lebih dari sepertiga penderitanya (35\%) dari total kasus di dunia, tingkat infeksi COVID-19 cenderung tinggi $^{1}$ (The Telegraph, 2020). Setidaknya terdapat dua efek dari tingkat penyebaran cepat virus SARS-CoV-2. Pertama, interaksi fisik tidak dimungkinkan sebab penularannya melalui tetesan kecil (droplet), diperumit dengan penderita yang mayoritas tidak bergejala. Kedua, demarkasi antara negara maju dan berkembang seolah menjadi lebur ketika dilihat dari sudut pandang strategi respon tiap negara.

Akibat dari kompleksitas tersebut, hingga saat ini, belum ada basis indikator dan ukuran internasional yang dapat digunakan untuk memprediksi bagaimana performa tiap negara merespons COVID-19. Negara dengan ekonomi yang besar belum tentu dapat merespons pandemi dengan mumpuni. Begitu pula status negara maju sesuai kategorisasi World Bank, atau performa baik di tahun-tahun sebelumnya dalam Human Development Index (HDI) keluaran United Nations Development Program (UNDP) tidak dapat digunakan untuk memetakan bahwa respon kebijakan terhadap pandemi akan lebih baik daripada negara-negara di urutan terbawah. Sebut saja Amerika Serikat (AS), ekonomi nomor satu di dunia (IMF 2020), yang masih berkutat dengan jutaan kasus dengan kematian hingga 168.696 jiwa, serta kurva kasus yang masih fluktuatif per Agustus 2020 (CDC 2020). AS bahkan menempati urutan kedua terbawah dari segi penurunan kasus COVID-19 baru (EndCoronavirus.org 2020). Norwegia yang menempati urutan teratas di peringkat HDI UNDP juga mengalami kenaikan kasus hingga hari ini dan sepekan lalu menunda rencana relaksasi kebijakan lockdown (Reuters 2020). Hingga saat ini, negara tersebut memiliki total 9.965 kasus (WHO

1 Ini berdasarkan asumsi terkini, namun, angka rasio infeksi belum dapat dipastikan dan masih dinamis. Ini disebabkan oleh total penderita tidak bergejala yang tidak terdeteksi, serta perbedaan metode kalkulasi kasus tiap-tiap negara (WHO 2020). 
2020)-tergolong kecil dibandingkan negara-negara tetangga, namun kurva kasus baru COVID-19 masih fluktuatif.

Dinamika yang tidak jauh berbeda juga dialami oleh Inggris. Walaupun tergolong telah mengalami penurunan kasus dan kematian akibat COVID-19, serta merelaksasi kebijakan lockdown, pemerintah Inggris sempat menuai kontroversi ketika mencanangkan rencana kebijakan kekebalan kelompok (herd immunity) di awal pandemi (The Guardian 2020). Hingga saat ini, Inggris masih menempati posisi ketiga tertinggi di wilayah Eropa dengan 316.367 kasus kumulatif per 14 Agustus 2020. Angka ini menyusul Rusia (917.884 kasus) dan Spanyol (342.813 kasus) (ECDC 2020a). Namun, dengan 41.358 kasus kematian per Agustus 2020, Inggris menempati peringkat tertinggi untuk jumlah kematian di wilayah Eropa (ECDC 2020a). Sehingga jika dibandingkan, Inggris memiliki tingkat kematian sebesar $13 \%$ dibanding Rusia $(1,7 \%)$ dan Spanyol $(8,3 \%)$ dari total kasus COVID-19 di tiap negara (diolah berdasarkan data ECDC 2020a).

Hal ini menjadikan Inggris sebagai salah satu negara dengan kebijakan COVID-19 yang menarik untuk dikaji. Tulisan ini akan menganalisis kebijakan pemerintah Inggris-tidak mencakup Skotlandia, Wales, dan Irlandia-dalam tiga aspek utama: kesehatan, ekonomi, dan sosial. Perencanaan kebijakan dikaji melalui konsep syndemic (Singer 2009) yang awalnya digunakan untuk memetakan keterhubungan dampak kesehatan akibat pandemi dengan aspek-aspek non-ekonomi ketika HIV/AIDS muncul tahun 1990-an. Hal penting lainnya ialah kesuksesan implementasi kebijakan pemerintah dalam menangani pandemi terletak dalam kemampuan kerjasama baik direfleksikan melalui tingkat kepercayaan, pembagian sumber daya, serta pengambilan keputusan konsensus antara otoritas, bisnis, non-profit dan publik. Pendekatan ini dikenal dengan whole-of-society (Schwartz \& Yen 2017, 125-132).

Struktur tulisan ini terdiri dari lima bagian. Pertama, membahas definisi konsep whole-of-society dan syndemic-pandemic. Kedua, perkembangan situasi COVID-19 di Inggris sejak bulan Januari hingga Juni dari aspek kesehatan (jumlah kasus dan kematian), ekonomi (kondisi makro), dan sosial (ketimpangan terhadap kaum minoritas). Ketiga, perjalanan kebijakan pemerintah Inggris sejak 
Januari hingga Juni. Keempat, analisis kesuksesan kebijakan berlandaskan kedua konsep tersebut dan terakhir simpulan.

\section{Lensa Syndemic-Pandemic dan Pendekatan Whole-Of- Society}

Setidaknya dua konsep dapat digunakan untuk merencanakan dan mengimplementasikan kebijakan terkait COVID-19 yakni syndemic-pandemic dan whole-of-society, keduanya menitikberatkan pada pendekatan multisektoral. Singer (2009) mendefinisikan syndemic sebagai koneksi antara krisis kesehatan berkepanjangan yang mengakibatkan memburuknya situasi kesehatan publik dan penurunan kualitas komponen sosial. Menggunakan pendekatan Singer (lihat Ilustrasi 1), Bambra (2020) mengidentifikasi bahwa komunitas yang berada di titik rapuh-kelompok minoritas, kelompok yang hidup di wilayah yang kurang layak, mereka yang prasejahtera, tuna wisma, residivis, maupun pekerja seksual-mengalami situasi kesehatan (komorbiditas) dan sosial yang memburuk akibat pandemi. Hal ini akibat kesenjangan tempat mereka tinggal yang mencakup tingkat pendidikan, akses terhadap pangan, lingkungan kerja, tingkat pengangguran, akses layanan kesehatan, serta kondisi tempat tinggal yang layak (Bambra 2020, 3). Melalui studi yang sama, syndemic termanifestasi dalam beberapa hal seperti durasi kerja panjang bagi masyarakat minoritas yang bekerja di sektor frontline; sehingga rentan terjangkit virus, perbedaan akses terhadap layanan kesehatan, serta kondisi tempat tinggal yang layak; untuk memastikan dapat menjaga jarak (Bambra 2020; Lacobucci 2020). 


\section{Gambar 1.}

\section{Pilar-Pilar Syndemic-Pandemic}

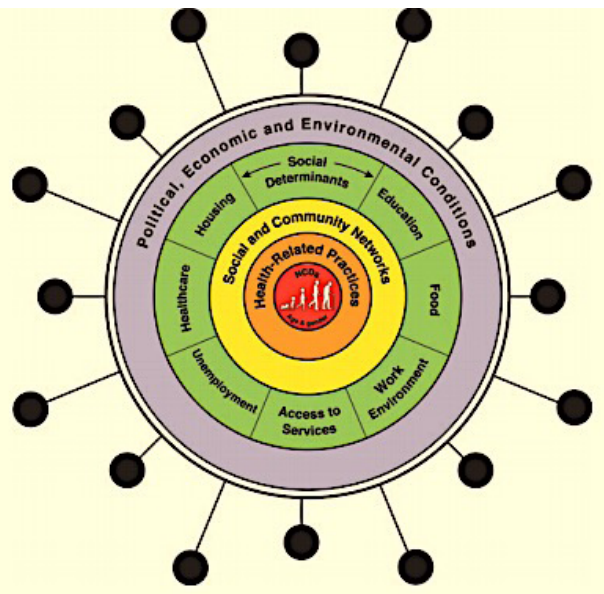

Sumber: Singer (2009) dan Bambra (2020)

Ketimpangan isu multisektoral tersebut dapat dijembatani dengan menjamin kolaborasi antara pemerintah, sektor privat, non-profit, serta masyarakat. Pendekatan whole-of-society ini direkomendasikan WHO (Schwartz dan Yen 2017) berangkat dari dalil bahwa menghadapi pandemi membutuhkan kolaborasi berbagai pihak mulai tahap perencanaan hingga implementasi. Kolaborasi ini meliputi diseminasi informasi, edukasi masyarakat, distribusi sumber daya yang dibutuhkan, hingga alternatif pembiayaan (WHO 2009; Ansell 2000; Provan dan Kenis 2008). Seringkali pihak otoritas berusaha menerapkan protokol-protokol kesehatan ekstrem seperti lockdown yang berimbas pada berbagai sektor, sehingga membutuhkan kepatuhan publik untuk menjamin tingkat keberhasilan (Schwartz dan Yen 2017). Kolaborasi ini juga dapat meningkatkan resiliensi (Kapucu 2005) dan juga mereduksi potensi politisasi isu. Tulisan ini membahas keadaan Inggris dari aspek kesehatan, ekonomi, dan sosial terkait pandemi COVID-19 per bulan Juni 2020, serta respon-respon kebijakan yang telah diambil pemerintah semester pertama 2020. 


\section{Situasi Umum Inggris}

Inggris mendeteksi kasus pertama COVID-19 tertanggal 3 Februari 2020 sebanyak 1 kasus dan jumlah ini fluktuatif sampai tanggal 26 Februari 2020 dengan rerata penurunan ke o kasus dan kenaikan sebanyak 2 kasus. Sejak 26 Februari 2020 hingga 7 April 2020, kasus baru bertambah hingga puncaknya di angka 4.579 dan turun sebanyak 50\% penambahan kasus baru pada 12 April 2020, sebelum kemudian kembali merangkak naik hingga titik tertinggi per hari sebesar 4.798 kasus per 22 April (gov.uk 2020b). Sejak 22 April 2020, kurva penambahan kasus baru melandai sampai di titik 500-an penambahan kasus per hari di penghujung bulan Juni 2020 (lihat Grafik 1). Sedangkan, data kasus kumulatif per akhir Juni 2020 mencapai 244.330 kasus (lihat Grafik 2). Jumlah kematian mengalami kenaikan sejak 23 Maret 2020 sebanyak 67 kematian setelah mengalami fluktuatif kasus kematian dengan rerata 21,5 kematian per hari selama 11 hari sebelumnya (lihat Grafik 3). Total kematian di Inggris per 30 Juni 2020 mencapai 35.848 kasus (lihat Grafik 4). Rasio kematian (CFR) mencapai 14,6\% pada penghujung Juni 2020 (olahan data berdasarkan gov. uk 2020b).

Kenaikan penambahan kasus sejak Februari sampai minggu ke-3 bulan April serta total tingkat kematian yang cukup tinggi menghadirkan pertanyaan tentang kemudahan mengakses tes COVID-19, baik melalui antibodi maupun polymerase chain reaction (PCR), serta kapasitas rawat inap rumah sakit. Terdapat empat cara untuk mengakses perangkat tes COVID-19 di Inggris; tes di rumah (home test kit), pusat tes (satellite test centers), unit tes berpindah (mobile testing units), dan pusat tes wilayah (regional test sites). Setidaknya per awal Juni 2020, kapasitas tes COVID-19 di Inggris mampu mencapai 200,000 tes per hari (gov.uk 2020k). Ini mencakup tes yang dijalankan oleh rumah sakit pemerintah melalui National Health Service (NHS) maupun yang dapat diakses pribadi melalui penyedia jasa sektor privat, seperti apotek maupun layanan kesehatan daring (gov.uk 2020k). Setidaknya sejak dimulai pada 28 Mei, 1.9\% dari total penduduk yang mengakses perangkat tes terdiagnosis positif (gov.uk 2020k). Menurut pidato Menteri Kesehatan dan Sosial Inggris, Matt Hancock, setidaknya 5,7 juta tes COVID-19 telah dilakukan per 8 
Juni 2020 (gov.uk 2020f).

Grafik 1.

Penambahan Kasus Baru Per Hari [COVID-19]

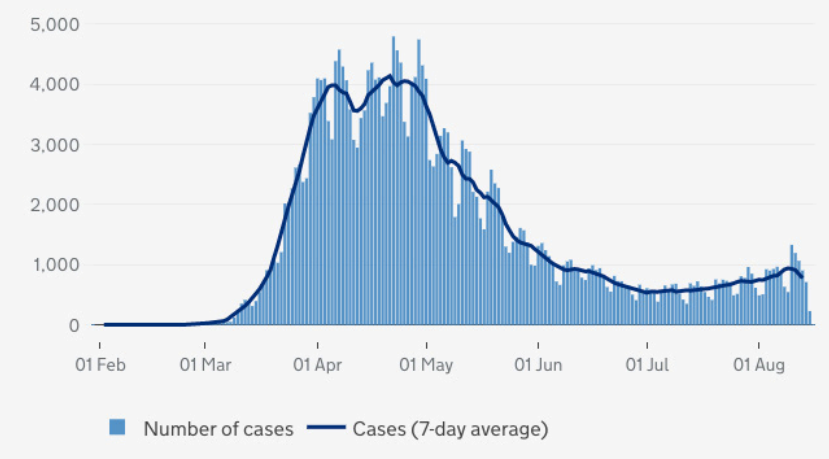

Sumber: gov.uk (2020b)

Grafik 2.

Kasus Kumulatif Per Hari [COVID-19]

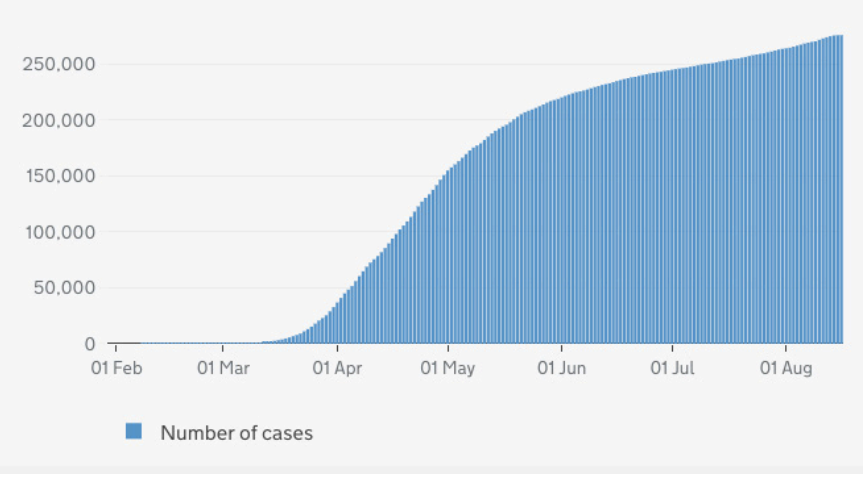

Sumber: gov.uk (2020b) 


\section{Grafik 3.}

\section{Penambahan Kematian Per Hari [COVID-19]}

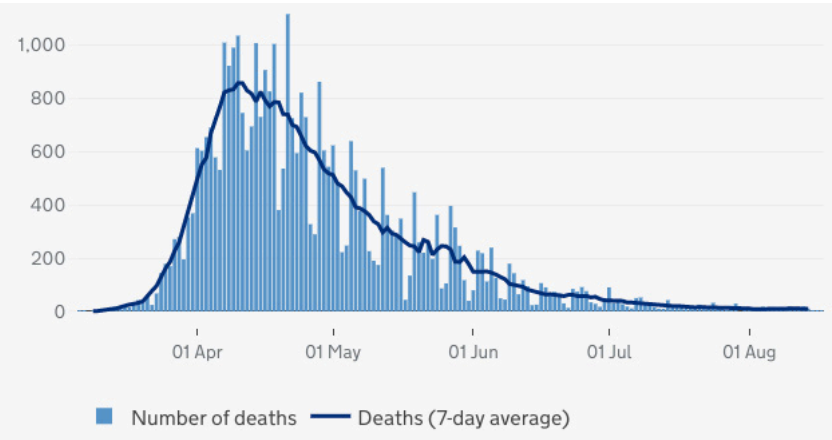

Sumber: gov.uk (2O2Ob)

Grafik 4.

Kumulatif Kematian Per Hari [COVID-19]

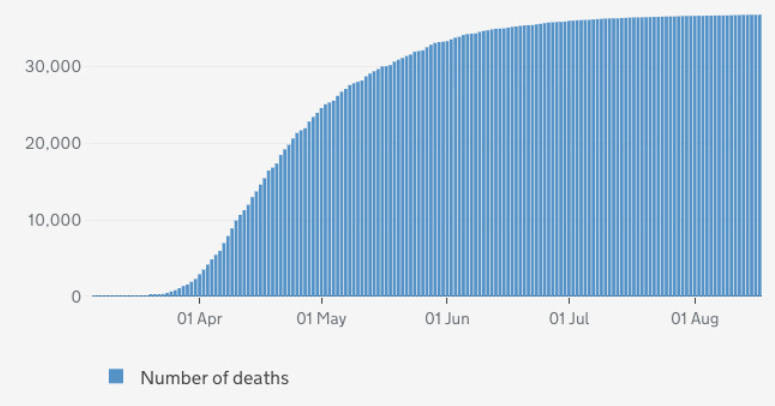

Sumber: gov.uk (2O2Ob)

Dalam kaitannya dengan kemampuan perawatan rumah sakit, jumlah pasien harian tertinggi yang dirawat sebanyak 3.099 pasien pada 31 Maret 2020 dan senantiasa menurun hingga 201 pasien baru yang dirawat per hari di penghujung bulan Juni 2020 (gov. uk 2020b). Sedangkan, 12 April 2020 menjadi hari dengan jumlah pasien tertinggi membutuhkan ventilasi sebanyak 2.881 pasien dengan fluktuatif kebutuhan ventilasi hingga 18 April 2020, diikuti dengan penurunan pasien membutuhkan ventilasi setelah hari tersebut (gov.uk 2020b). Pada penghujung bulan Juni, sebanyak 238 pasien membutuhkan ventilasi (gov.uk 2020b)-penurunan 
sebanyak 90\% dari kebutuhan pada April 2020.

DarisegiekonomiperJuni2020,jumlah orangyang diklasifikasikan sebagai inactive atau tidak mampu mencari pekerjaan mencapai 301.000 orang (BBC 2020c). Produk domestik bruto (PDB) Inggris meluncur tajam ke angka -2,2\%; situasi terendah sejak tahun 1979 (BBC 2020a). Ini diakibatkan oleh konsumsi rumah tangga yang menurun drastis akibat lockdown, penurunan aktivitas sektor jasa, serta penurunan produksi manufaktur akibat tutupnya pabrik (BBC 2020d). Simply Business (2020) juga mengestimasi kerugian bisnis skala kecil sebanyak 1,347 triliun rupiah, situasi yang lebih buruk daripada krisis ekonomi 2008.

Ini berimbas pada sektor sosial di Inggris; peningkatan jumlah pengangguran, penurunan jumlah lowongan kerja akibat berkurangnya jam kerja selama lockdown, serta penurunan pendapatan. Kelompok-kelompok rentan seperti mereka yang bekerja dalam sektor frontline, remaja, serta kelompok lansia terdampak. Selain itu, ketimpangan sosial berkorelasi dengan mortalitas; setidaknya $15.5 \%$ etnis kulit hitam dan Asia menjadi bagian dari proporsi jumlah kematian akibat COVID-19 (BBC 2020e). Menurut data UK Office of National Statistics (2020), tingkat kematian akibat COVID-19 di komunitas termiskin di Inggris dua kali lipat lebih besar apabila dibandingkan dengan mereka yang bertempat tinggal di wilayah berpendapatan tinggi. Walaupun tidak konklusif, hal ini bersumber dari perbedaan kepadatan rumah tangga antara etnis mayoritas (kulit putih) dan etnis minoritas yang mana hanya $2 \%$ rumah tangga etnis kulit putih diklasifikasikan dalam kategori sangat padat, sedangkan 15\% rumah tangga etnis kulit hitam diklasifikasikan dalam kategori sangat padat (BBC 2020e). Selain itu, hal serupa juga ditunjukkan oleh situasi tempat tinggal tuna wisma yang cenderung padat. Setidaknya terdapat 320.000 total tuna wisma di Inggris (Shelter 2020), dan hanya 30.000 yang dapat menempati penampungan selama COVID-19. 


\section{Resep Pemerintah: Menakar Kapasitas Otoritas}

Seruan kontroversial pemberlakuan kebijakan herd immunity (BBC 2020b)-total populasi sebanyak mungkin terjangkit virus agar antibodi dapat terbentuk dengan sendirinya-dicabut karena reaksi publik yang menggarisbawahi pentingnya vaksin sebelum menerapkan kebijakan ini (FT, 2020). Ini merupakan respon pertama pemerintah Inggris ketika kasus COVID-19 mulai merebak. Kebijakan pemerintah Inggris dalam merespons pandemi dikenal dengan: four-pronged plan yang terdiri dari contain (mendeteksi kasus awal), delay (menurunkan penyebaran virus), research (melakukan penelitian lebih lanjut terkait penyakit untuk merespons kenaikan kasus dengan baik), dan mitigate (mendukung mereka yang sakit, komunitas rentan, dan layanan kesehatan) (gov.uk 2020c). Keempat fase ini dijalankan bersinergi.

Pada 16 Maret 2020, Perdana Menteri (PM) Boris Johnson menghelat konferensi pers pertama terkait COVID-19. Ia meminta para pekerja di Inggris tidak beraktivitas ke kantor serta menghindari klub malam (Institute for Government, 2020a). Awal Maret 2020, Pemerintah Inggris juga membentuk The National Supply Distribution Response Team untuk memastikan ketersediaan alat pelindung diri (APD) dengan rincian 170 juta masker, 42,8 juta sarung tangan lateks, 13,7 juta apron, 182.000 gaun dokter, 10 juta peralatan alat kebersihan, serta 2,3 juta pasang pelindung mata (gov.uk 2020a). Selain itu, National Health Service (NHS) sebagai penyedia asuransi nasional juga mengirimkan surat berisikan anjuran wajib bagi kelompok rentan-asma, diabetes, hipertensi, dan komorbiditas lainnya-untuk tetap diam di rumah selama 12 minggu sejak akhir Maret 2020 (gov.uk 2020a). Mereka yang menerima surat ini akan menerima suplai makanan harian. Selain itu, NHS juga membangun sistem yang dikenal dengan NHS Voluntary Responders yang mana masyarakat tidak rentan dapat mendaftar sebagai bagian relawan untuk mengantarkan suplai makanan pada mereka yang rentan, atau sekadar melakukan kontak telepon untuk mereka yang diisolasi dan membutuhkan dukungan mental (gov.uk 2020a).

Kebijakan lockdown diterapkan dalam tiga fase berbeda. Pertama dimulai pada 26 Maret 2020 dengan kebijakan diam di rumah 
(stay-at-home) diumumkan melalui jargon Save NHS, Save Lives, diikuti dengan tutupnya berbagai fasilitas publik untuk menjamin jarak fisik (Institute for Government 2020b), serta diawali penutupan bisnis sejak 21 Maret 2020 (gov.uk 2020d). Masyarakat tidak diperkenankan untuk meninggalkan rumah, kecuali untuk membeli bahan pangan utama dan berolahraga tidak lebih dari enam puluh menit. Ketika melakukan aktivitas luar rumah, seseorang hanya diperbolehkan mengajak mereka yang berasal dari rumah tangga yang sama, serta senantiasa menjaga jarak dengan anggota rumah tangga lain yang kebetulan sedang melakukan aktivitas di tempat yang sama (legislation.gov.uk 2020). Kedua ialah relaksasi lockdown pada 11 Mei 2020-dengan tinjauan situasi saat itu-yang mana masyarakat diperkenankan untuk berolahraga di luar ruangan tanpa batasan, serta dapat mengendarai kendaraan ke tempat lainnya. Ketiga dimulai pada 1 Juni 2020 yakni ketika masyarakat diperkenankan untuk keluar rumah, dapat berkumpul dengan maksimal 6 orang dari anggota rumah tangga lain di tempat terbuka dengan memperhatikan jarak fisik satu sama lain, serta retail mulai dibuka pada 15 Juni 2020 dengan praktik jarak fisik serta penggunaan masker di seluruh transportasi publik.

Kebijakan lainnya, menargetkan NHS Test and Trace atau sistem pendeteksian kasus COVID-19 dengan kombinasi tes rumah sakit dan tes mandiri dilakukan oleh pemerintah serta sektor privat, ditambah dengan mendata pergerakan masyarakat Inggris dengan mengisi laman daring untuk mempermudah pelacakan ketika isolasi dibutuhkan (Institute for Government 2020b). Target ini diharapkan mencapai 200.000 per hari pada Juni 2020 (gov.uk 2020f). Sejak 17 April 2020, semua pekerja frontline dan esensial, termasuk mereka yang bekerja di supermarket maupun melayani anak kecil terlantar, korban kekerasan domestik, dan tuna wisma, didahulukan dalam mengakses tes COVID-19 (gov.uk 2020e).

Dalam melancarkan kebijakan lockdown, Kementerian Dalam Negeri mengerahkan peran polisi untuk meminta masyarakat kembali ke rumah serta mengenakan denda ketika masyarakat melanggar ketentuan larangan di tiap fase lockdown yang telah ditentukan. Untuk menunjang performa kepolisian, utamanya terkait sumber daya, pemerintah Inggris juga merelaksasi pajak 
yang harus dibayarkan oleh anggota kepolisian yang bertugas serta aturan usia pensiun sehingga mereka tetap dapat bekerja untuk menerapkan aturan lockdown. Selain itu, pemerintah juga menjalin komunikasi dengan Security Industry Authority demi mengundang sektor privat yang memiliki bisnis dalam bidang penyedia tenaga keamanan untuk membantu anggota kepolisian (gov.uk 2020g). Terkait kelompok rentan, Kementerian Dalam Negeri mengalokasikan 386 milyar rupiah untuk hotline pengaduan serta penanganan kekerasan domestik dan kekerasan seksual terhadap anak di bawah umur selama lockdown (gov.uk 2020g).

Kementerian Perumahan juga merilis kebijakan pada Mei 2020 untuk memberikan keringanan sebesar $5 \%$ bagi tenaga kesehatan NHS dalam mengakses tempat tinggal didukung oleh sektor privat (gov.uk 2020h). Sebelum memasuki fase penyesuaian lockdown yang terakhir, Charter for Safe Working Practice juga dirilis oleh Kementerian Perumahan untuk memastikan penyedia jasa perumahan telah mematuhi protokol kesehatan. Terkait tunjangan pendukung terhadap pekerja frontline dan esensialtenaga kesehatan, staf lembaga permasyarakatan, kepolisian, serta guru-akan menerima kenaikan gaji dengan kisaran 2\%3.1\% (gov.uk 2020i). Kenaikan ini akan diakumulasi dimulai dari pembayaran penerimaan gaji sejak bulan April.

Dari segi bantuan ekonomi dan sosial, Chancellor (setara dengan Menteri Keuangan) Rishi Sunak meluncurkan program bantuan pinjaman sebesar 6,000 triliun rupiah dan pemotongan pajak senilai 386 triliun rupiah untuk sektor bisnis. Bantuan darurat COVID-19 lainnya berupa dukungan dana terhadap pemerintah lokal, mendanai pangan untuk kelompok rentan, menghapus pajak untuk produsen APD, mengalokasikan bantuan dana untuk yayasan sosial yang membantu kelompok rentan, menanggung biaya operasional bisnis, termasuk gaji pegawai, agar bisnis kecil dan menengah tidak memberhentikan pegawai, menanggung pendapatan wiraswasta dengan ketentuan tertentu, menanggung bayaran akibat jatuh sakit, serta memberikan bantuan tunai dan tempattinggaluntukmerekayangberpenghasilan rendahatautidak bekerja (Institute for Government 2020b). Selain itu, pemerintah Inggris juga membantu pemerintah lokal dan relawan dalam 
merespons permasalahan tuna wisma dengan mengalokasikan 40 triliun rupiah agar para tuna wisma dapat menempati hotelhotel yang kosong akibat lockdown, pun memisahkan antara tuna wisma bergejala dan tidak bergejala (Crisis 2020; Kirby 2020). Selain bantuan pemerintah, organisasi-organisasi sosial merekrut ribuan relawan untuk membantu mengantar makanan dengan protokol tertentu untuk mereka yang terdiagnosis positif dan harus mengisolasi diri, serta membantu kelompok rentan bertahan dalam situasi lockdown (The Guardian 2020).

\section{Analisis Koordinasi Multisektoral Isu dan Aktor}

Terdapat dua hal yang dapat dianalisis dari berbagai kebijakan yang telah diluncurkan pemerintah Inggris melalui lensa syndemicpandemic dan whole-of-society, yakni kepekaan terhadap kompleksitas isu serta keterlibatan dan resiliensi aktor di luar pemerintah, yakni komunitas, individu, dan masyarakat. Memang tidak dapat dibantah jika pemerintah Inggris patut dikritik di awal terkait kebijakan herd immunity yang mencanangkan 40 juta masyarakat Inggris (FT 2020) perlu terjangkit COVID-19 untuk membentuk antibodi. Setidaknya 229 peneliti, baik medis dan non-medis, menyampaikan surat terbuka pada pemerintah dan mendorong mereka untuk melancarkan kebijakan yang lebih ketat dan disiplin demi menurunkan kasus serta implikasi jangka panjang pada 14 Maret 2020 (BBC 2020b). Selain itu, Scally et al (2020) juga menekankan bahwa hasil modelling dilakukan oleh epidemiologi terkait rencana herd immunity akan memakan korban hingga 250.00o jiwa. Atas angka ini, pemerintah berputar arah.

Petisi awal kelompok epistemik dan hasil modelling yang direspons pemerintah kurang dari sepekan ini merupakan refleksi parsial bagaimana pendekatan whole-of-society bekerja; inklusif dan siap mendengar aktor dari segala sisi. Namun, pertanyaan lain muncul atas proses yang tidak inklusif saat perencanaan kebijakan. Ini terlihat dari tidak adanya upaya melibatkan pandangan ilmuwan di luar lingkaran pemerintah sebelum memutuskan pernyataan publik tentang herd immunity. Respon ini pun terkesan reaktif, daripada proaktif. Ini dibuktikan dengan 
bagaimana PM Boris Johnson menggelar konferensi pers pada 16 Maret 2020 (Institute for Government 2020a) untuk menjawab desakan kelompok epistemik, masyarakat dan tekanan politik untuk meluncurkan kebijakan yang lebih pakem. Akar masalah dari keterlambatan penerapan kebijakan sebelumnya terletak pada perampingan lembaga-The Health Protection Agency dan tim kesehatan regional telah dihapus per awal 2020-berganti fungsi dengan politisi yang mendorong kebijakan tidak terbuka dan tidak berbasis sains (Scally et al 2020).

Selain itu, kebijakan lockdown yang baru diterapkan di Inggris setelah kenaikan kematian dari COVID-19 sejak 23 Maret 2020 serta fluktuatif jumlah kasus sejak Februari 2020 menunjukkan diperlukannya kebijakan lebih disiplin lebih awal. Sebut saja kebijakan negara tetangga di Eropa-Italia, misalnya, yang telah melakukan lockdown dua pekan lebih awal (Scally et al 2020). Ini berimplikasi pula dengan bagaimana publik merespons kebijakan lockdown yang diumumkan satu minggu setelah ekspektasi lockdown akan dilaksanakan pada 16 Maret 2020. Survei yang dirilis Ofcom (2020) menunjukkan bahwa masyarakat Inggris tidak lagi menunggu dan menyaksikan secara langsung arahan PM di televisi, melainkan, berlandaskan pada headline dan bagaimana media melakukan framing terhadap pernyataan publik pemerintah. Ini menimbulkan pertanyaan terkait tingkat kepercayaan publik terhadap pemerintah dan bagaimana ini memengaruhi kepatuhan publik terhadap aturan-aturan yang dirilis.

Namun, tanggapnya pemerintah Inggris setelah keterlambatan di awal setidaknya patut diapresiasi. Pertama, pemerintah berhasil menekan total kenaikan kasus per hari hampir 90\% setelah melaksanakan 3 bulan kebijakan lockdown yang pada esensinya tidak melarang semua kegiatan luar rumah; masih ada ruang untuk berolahraga, misalnya. Ini berarti pilar kesehatan dalam pendekatan syndemic tercapai. Tetapi, ini juga menjadi preseden lain; tidak semua kelompok dapat merasakan keistimewaan berdiam di rumah dan menikmati olahraga luar rumah, utamanya mereka yang berasal dari kelompok rentan.

Kedua, berkaitan dengan hal tersebut, pembentukan kebijakan pemerintah Inggris yang holistik-mempertimbangkan kelompok 
tuna wisma serta yayasan yang bekerja untuk kelompok rentansetidaknya menunjukkan perencanaan kebijakan yang peka akan syndemic yang mana lensa ekonomi dan sosial dipertimbangkan. Bantuan tunai keuangan untuk kelompok-kelompok ini serta mereka yang diberhentikan kerja atau mengalami penurunan pendapatan juga menunjukkan bahwa konsentrasi respon krisis tidak hanya berbasis kesehatan, namun juga mempertimbangkan ekses terhadap sektor lain.

Ketiga, meletakkan prioritas untuk pekerja frontline dalam mengakses perlengkapan tes COVID-19, menjamin ketersediaan APD, serta kenaikan upah menggarisbawahi bagaimana pemerintah dan masyarakat Inggris tidak dapat bertahan sendiri, serta meletakkan penghargaan bagi frontliners yang bekerja di bawah tekanan di tengah krisis.

Keempat, deliberasi kebijakan pemerintah untuk mempertimbangkan kebutuhan relawan dalam mendukung mereka yang terisolasi, maupun mereka yang membutuhkan dukungan mental, pun dukungan terhadap pemerintah lokal, juga menunjukkan kolaborasi yang mana digarisbawahi dalam pendekatan whole-of-society. Terakhir, kerjasama pemerintah dengan aktor-aktor non-pemerintah (bisnis, lembaga sosial, serta sektor privat) dalam mengimplementasikan kebijakan-aturan lockdown, pengadaan peralatan tes COVID-19, serta merespons mereka yang rentan-baik dalam bentuk insentif finansial maupun bantuan tunai menegaskan bahwa pendekatan whole-of-society dan syndemic merupakan titik awal yang baik untuk merespons krisis kesehatan, utamanya perihal alokasi sumber daya serta pengambilan konsensus selama proses krisis (Schwarts dan Yen 2017).

Namun, terlepas dari lima elemen kebijakan yang bersinergi, beberapa hal terkait implementasi lapangan masih menjadi pertanyaan sejauh mana kolaborasi negara dan aktor non-negara dalam whole-of-society dapat diterapkan. Pertama, mengenai penerapan aturan relaksasi lockdown (penggunaan masker di publik dan jarak fisik). Menurut survei YouGov (2020) pada Maret-Juni 2020, masyarakat Inggris secara konsisten berada di tingkat terendah (hanya 21\% dari sampel) dalam menaati aturan mengenakan masker di publik, dibandingkan dengan Tiongkok 
(90\%), India (80\%), Singapura (80\%), Australia (29\%), Italia (mendekati 90\%), Spanyol (mendekati 90\%), Perancis (mendekati 80\%), Jerman (65\%), Meksiko (mendekati 70\%), Amerika Serikat (mendekati 70\%), dan Kanada (50\%). Hanya negara-negara Skandinavia yang notabene memiliki tingkat lebih rendah dalam menggunakan masker di publik yakni kurang dari 10\% apabila dibandingkan dengan Inggris (YouGov, 2020). Ini berarti pilar masyarakat Inggris tidak benar-benar bersinergi dalam keseharian dengan kebijakan yang dirilis pemerintah. Tetapi, ini juga kembali pada masalah komunikasi politik dan penerapan yang ambivalen. Pemerintah Inggris hanya mengimbau mengenakan masker di awal: wear a mask if you can, daripada mewajibkan hal tersebut atau hanya menempatkan ketentuan denda oleh polisi sebagai last resort. Ini ditunjukkan melalui data bahwa dari total 54.00o masyarakat di London diperingatkan oleh polisi untuk mengenakan masker, hanya 33 orang yang dikenakan denda (The Telegraph 2020).

Kedua, terkait efektivitas bantuan tunai langsung untuk meringankan beban mereka yang rentan atau dalam mengatasi ketimpangan. Setidaknya analisis Institute for Public Policy Research (2020) mengestimasi bahwa 1 juta penduduk di Inggris akan masuk ke dalam kategori miskin per akhir 2020 akibat COVID-19, ini termasuk 200.00o anak. Koalisi yayasan sosial juga mempublikasikan petisi agar pemerintah mempercepat distribusi bantuan tunai pada masyarakat rentan, utamanya menjamin pasokan makanan bagi unit keluarga. Food bank di Inggris menunjukkan kenaikan sebesar 89\% kebutuhan selama COVID-19 diikuti dengan jumlah keluarga dua kali lipat mengunjungi food bank untuk memperoleh makanan (Trussel Trust 2020). Ini menghadirkan pertanyaan baru terkait dampak jangka panjang relaksasi lockdown sebelum penemuan vaksin akan tetap efektif untuk penurunan kasus, utamanya dampak yang dirasakan kelompok minoritas (black, Asian, and minority ethnics; BAME) (Alderwick et al 2020).

Terakhir, situasi makroekonomi jangka panjang yang tidak pasti masih memiliki ruang untuk dikritisi. Efek nyata dari bantuanbantuan finansial dan insentif pun tidak benar-benar dapat disimpulkan saat ini, tetapi dapat dianalisis setelah program selesai 
dilaksanakan-setelah Oktober. Data-data di lapangan hingga saat ini menggarisbawahi masih adanya jarak antara perencanaan dan implementasi di lapangan untuk mengerahkan kolaborasi antar aktor dalam merespons pandemi di Inggris. Keadaan-keadaan di lapangan juga menampilkan ketimpangan yang selama ini tidak terlihat di permukaan. Memperhatikan hal-hal diatas, dapat dikatakan bahwa pemerintah Inggris menunjukkan kebijakan berbasis learn-to-reflect. Namun, implementasi di lapangan masih membutuhkan puluhan bahkan ratusan proses learn-toreflect, utamanya dalam mengkaji dan merespons kemampuan jangka panjang masyarakat rentan untuk menghadapi ekses-ekses ekonomi dan sosial dari COVID-19.

\section{Simpulan}

Kebijakan pemerintah Inggris menangani COVID-19 awalnya sempat menuai kontroversi akibat keterlambatan, pencanangan kebijakan ekstrem tidak berbasis sains, serta ambivalensi komunikasi politik di hadapan publik. Namun, kontroversi tersebut menjadi bagian besar dari bentuk learn-to-reflect pemerintahan Inggris. Learn-to-reflect merujuk pada adanya kemampuan pemerintahan Inggris untuk mengubah kebijakan kontroversi di awal menjadi kebijakan yang tepat guna. Hal ini terlihat pada beberapa sektor seperti kesehatan, ekonomi serta sosial. Pada sektor kesehatan secara umum Inggris mampu menekan angka kasus harian dan kematian. Pada sektor ekonomi respon pemerintah Inggris dapat mendukung mereka yang terancam diberhentikan, yang menganggur, serta bisnis-bisnis UMKM. Pada bidang sosial, pemerintah Inggris mampu menjamin tersedianya bantuan untuk kelompok prasejahtera, tuna wisma, lansia, serta rentan terhadap COVID-19. Proses kebijakan learnto-reflect ini dibuktikan dengan efektivitas pendekatan syndemic; mempertimbangkan keterhubungan antara krisis kesehatan dan isu non-kesehatan serta whole-of-society. Keberhasilan Inggris ini tidak kemudian membuat strategi learn-to-reflect menjadi sempurna karena masih ada hal-hal yang masih perlu diperhatikan lebih lanjut seperti efektivitas relaksasi lockdown, efek bantuan keuangan dan ketimpangan sosial di masyarakat, serta jaminan terjaganya jumlah kasus baru COVID-19 pada titik minimal setelah 
Juni 2020. COVID-19 sebagai pandemi baru membutuhkan proses pembelajaran, sinergi, dan refleksi yang tidak terhenti. Negara yang dapat merespons dengan efisien ialah yang mampu menunjukkan inklusivitas dan fleksibilitas dalam kebijakannya untuk menjalin kolaborasi antar aktor dalam menerapkan pendekatan yang lebih baik dari kebijakan sebelumnya.

\section{Referensi}

\section{Jurnal dan Artikel Jurnal}

Alderwick, Hugh et al., 2020. "England's health policy response to COVID-19”, BMJ;369:m1937.

Ansell, Chris, 2000. "The Networked Polity: Regional Development in Western Europe", Governance: An International Journal of Policy and Administration, 13 (3): 303-333.

Bambra, Clare et al, 2020. "The COVID-19 pandemic and health inequalities", J Epidemiol Community Health, doi:10.1136/ jech-2020-214401.

Kapucu, Naim, 2005. "Interorganizational coordination in dynamic context: networks in emergency response management", CONNECTIONS 26(2): 9-10.

Kirby, Tony, 2020. "Efforts escalate to protect homeless people from COVID-19 in UK", The LANCET Respiratory Medicine, 8(5): 447-449.

Lacobucci, Gareth, 2020. "Primary care networks: NHS England under pressure to rein in its ambitions", BMJ;368:m230.

Provan, Keith G \& Kenis, P., 2008. "Modes of network governance: structure, management, and effectiveness", Journal of Public Administration Research and Theory, 18(2): 229252.

Scally, Gabriel et al., 2020. "The UK's public health response to covid-19”, BMJ;369:m1932.

Schwartz, Jonathan dan Muh-Yong Yen, 2017. "Toward a collaborative model of pandemic preparedness and response: Taiwan's changing approach to pandemics”, $\mathrm{J}$ Microbiol Immunol Infect, 5O(2): 125-132.

Singer, M., 2017. "Syndemics and the biosocial conception of health", The Lancet 389.10072 (2017): 941-950. 


\section{Laporan Pemerintah}

Crisis, 2020. "Government response to homelessness and COVID-19", [daring]. dalam https://www.crisis.org. uk/media/241941/crisis_covid-19_briefing_2020.pdf [Diakses 16 Agustus 2020].

ECDC, 2020a. "Covid-19 situation update for the EU/EEA and the UK, as of 16 August 2020", [daring]. Dalam https://www. ecdc.europa.eu/en/cases-2019-ncov-eueea. [Diakses 16 Agustus 2020].

ECDC, 2020b. "Covid-19 situation update worldwide, as of 16 August 2020", [daring]. Dalam https://www.ecdc. europa.eu/en/geographical-distribution-2019-ncov-cases [Diakses 16 Agustus 2020].

ECDC, 2020c. "Q\&A on COVID-19", [daring] dalam https://www. ecdc.europa.eu/en/covid-19/questions-answers [Diakses 16 Agustus 2020].

gov.uk, 2020a. "Communities Secretary's statement on COVID-19: 29 March 2020", [daring]. Dalam https://www.gov.uk/ government/speeches/communities-secretary-robertjenrick-on-covid19-response [diakses 16 Agustus 2020].

gov.uk, 2020b. "Coronavirus (COVID-19) in the UK", [daring] dalam https://coronavirus.data.gov.uk/ [diakses 16 Agustus 2020].

gov.uk, 2020c. "Coronavirus action plan: a guide to what you can expect across the UK", [daring]. dalam https://www.gov. uk/government/publications/coronavirus-action-plan/ coronavirus-action-plan-a-guide-to-what-you-can-expectacross-the-uk [diakses 16 Agustus 2020].

gov.uk, 2020c. "Coronavirus outbreak FAQs: what you can and can't do", [daring]. dalam https://www.gov.uk/ government/publications/coronavirus-outbreak-faqswhat-you-can-and-cant-do/coronavirus-outbreak-faqswhat-you-can-and-cant-do [diakses 16 Agustus 2020]. 
gov.uk, 2020d. "Government sets out plans to enforce closure of businesses and other venues", [daring]. dalam https:// www.gov.uk/government/news/government-sets-outplans-to-enforce-closure-of-businesses-and-othervenues--2 [diakses 16 Agustus 2020].

gov.uk, 2020e. "Government to extend testing for coronavirus to more frontline workers", https://www.gov.uk/ government/news/government-to-extend-testing-forcoronavirus-to-more-frontline-workers [diakses 16 Agustus 2020].

gov.uk, 2020f. "Health and Social Care Secretary's statement on Coronavirus (COVID-19): 8 June 2020", [daring]. Dalam https://www.gov.uk/government/speeches/health-andsocial-care-secretarys-statement-on-coronavirus-covid19-8-june-2020 [diakses 16 Agustus 2020].

gov.uk, 2020g. "Home Secretary's statement on domestic abuse and COVID-19: 11 April 2020", [daring]. Dalam https:// www.gov.uk/government/speeches/home-secretaryoutlines-support-for-domestic-abuse-victims [diakses 16 Agustus 2020].

gov.uk, 2020h. "Housing Secretary's statement on COVID-19: 13 May 2020", [daring]. dalam https://www.gov.uk/ government/speeches/housing-secretarys-statement-oncoronavirus-covid-19-13-may-2020 [diakses 16 Agustus 2020].

gov.uk, 2020i. "Pay rises for doctors, police, and more in the public sector", [daring]. dalam https://www.gov.uk/government/ news/pay-rises-for-doctors-police-and-more-in-thepublic-sector [diakses 16 Agustus 2020].

gov.uk, 2020j. "New rules on face coverings coming in on Monday will help keep passengers safe", [daring]. Dalam https://www.gov.uk/government/news/new-rules-onface-coverings-coming-in-on-monday-will-help-keeppassengers-safe [diakses 16 Agustus 2020].

gov.uk, 2020k. "Weekly NHS Test and Trace bulletin, England: 
18 to 24 June 2020", [daring]. dalam https://www.gov.uk/ government/publications/nhs-test-and-trace-statisticsengland-18-june-to-24-june-2020/weekly-nhs-test-andtrace-bulletin-england-18-24-june-2020 [diakses 16 Agustus 2020].

legislation.gov.uk, 2020. "The Health Protection (Coronavirus, Restrictions) (England) Regulations 2020", [daring] dalam https://www.legislation.gov.uk/uksi/2020/350/ regulation/6/made [diakses 16 Agustus 2020].

Office of National Statistics, 2020. "Deaths involving COVID-19 by local area and socioeconomic deprivation: deaths occurring between1Marchand17April2020",[daring] dalam[https:// www.ons.gov.uk/peoplepopulationandcommunity/ birthsdeathsandmarriages / deaths / bulletins / deathsinvolvingcovid19bylocalareasanddeprivation/ deathsoccurringbetween1marchand17april [diakses 16 Agustus 2020].

\section{Artikel Daring}

BBC, 2020a. "Boris Johnson warns 'long, long way to go' for UK economy", 11 Agustus 2020 [daring] dalam https://www. bbc.co.uk/news/business-53733440 [Diakses 16 Agustus 2020].

BBC, 2020b. "Did herd immunity change the course of the outbreak?", 20 Juli 2020 [daring] dalam https://www.bbc. co.uk/news/uk-53433824 [Diakses 16 Agustus 2020].

BBC, 2020c. "Unemployment rate: how many people are out of work?", [daring]. dalam https://www.bbc.co.uk/news/ business-52660591 Diakses 16 Agustus 2020].

BBC, 2020d. "Coronavirus: UK economy hit by worst contraction in 41 years", 20 Juni 2020 [daring] dalam https://www. bbc.co.uk/news/business-53231851 [Diakses 16 Agustus 2020].

$\mathrm{BBC}$, 2020e. "Why are more people from BAME backgrounds dying from coronavirus?", 19 Juni 2020 [daring] dalam https://www.bbc.co.uk/news/uk-52219070. [Diakses 16 
Agustus 2020].

FT, 2020. "UK's chief scientific adviser defends 'herd immunity' strategy for coronavirus", 14 Maret 2020 [daring] dalam https://www.ft.com/content/38a81588-6508-11ea-b3f3fe4680ea68b5 [Diakses 16 Agustus 2020].

The Guardian, 2020. "Community aid groups set up across UK amid coronavirus crisis”, 16 Maret 2020 [daring] dalam https://www.theguardian.com/society/2020/ mar/16/community-aid-groups-set-up-across-uk-amidcoronavirus-crisis [Diakses 16 Agustus 2020].

The Telegraph, 2020. "How does coronavirus compare to flu, SARS, and other diseases?", 25 Maret 2020 [daring] dalam https://www.telegraph.co.uk/news/o/coronavirus-vssars-mers-flu-how-deaths-compare-covid-19/ [Diakses 16 Agustus 2020].

The Telegraph, 2020. "Police have reminded nearly 30,000 travellers to wear face masks but issued only 33 fines, official figures reveal", 8 Agustus 2020 [daring] dalam https://www.telegraph.co.uk/news/2020/o8/o8/policehave-reminded-nearly-3000o-travellers-wear-facemasks/ [Diakses 17 Agustus 2020].

The Telegraph, 2020. "What is coronavirus, how did it start and how big could it get?", 16 Agustus 2020 [daring] dalam https://www.telegraph.co.uk/news/o/what-coronavirushow-spread-uk-global-pandemic/ [Diakses 16 Agustus 2020].

\section{Lain-Lain}

Institute for Government, 2020a. "Boris Johnson's plan to ease the coronavirus lockdown", [daring]. dalam https://www. instituteforgovernment.org.uk/explainers/boris-johnsonplan-ease-coronavirus-lockdown [Diakses 16 Agustus 2020].

Institute for Government, 2020b. "Coronavirus: government support for businesses and individuals", [daring]. dalam https://www.instituteforgovernment.org.uk/ printpdf/9592 [Diakses 16 Agustus 2020]. 
Institute for Public Policy Research, 2020. "Estimating poverty impacts of the coronavirus pandemic", [daring] dalam https://www.ippr.org/files/2020-06/estimating-povertyimpacts-of-coronavirus.pdf [Diakses 17 Agustus 2020].

Ofcom, 2020. "BBC News and Current Affairs reviews: observing real news behaviors, detailed report", [daring] dalam https://www.ofcom.org.uk/__data/assets/pdf_ file/o028/174088/bbc-news-review-deck.pdf. [Diakses 17 Agustus 2020].

Simply Business, 2020. "Small businesses and COVID-19: how has your area been impacted?”, [daring] dalam https://www. simplybusiness.co.uk/knowledge/articles/2020/06/ covid-19-and-small-business-how-has-your-area-beenimpacted/ [Diakses 16 Agustus 2020].

Shelter, 2018. "320,000 people in Britain are now homeless, as numbers keep rising”, [daring] dalam https://england. shelter.org.uk/media/press_releases/articles/320,00o_ people_in_britain_are_now_homeless,_as_numbers_ keep_rising [Diakses 16 Agustus 2020].

Trussel Trust, 2020. "UK Food Banks report busiest month ever", [daring] dalam https://www.trusselltrust. org/2020/o6/o3/food-banks-busiest-month/ [Diakses 16 Agustus 2020].

UN DESA, 2020. "Everyone included: social impact of COVID-19", [daring] dalam https://www.un.org/development/desa/ dspd/everyone-included-covid-19.htmll] [Diakses 16 Agustus 2020].

YouGov, 2020. "COVID-19: Britons still won't wear face masks", [daring] dalam https://yougov.co.uk/topics/health/ articles-reports/2020/06/04/covid-19-britons-still-wontwear-face-masks [Diakses 16 Agustus 2020]. 
United Kingdom Effort to Combat COVID-19: Learn-to-reflect Policy 